\title{
Comparison of chemical and physical activation processes at obtaining adsorbents from Moroccan oil shale
}

\author{
Mina Oumam ${ }^{(\mathrm{b})}$, Abdelkrim Abourriche ${ }^{(\mathrm{a}) *}$, Said Mansouri ${ }^{(\mathrm{b})}$, \\ Mossaab Mouiya ${ }^{(\mathrm{a}, \mathrm{e})}$, Abdelaziz Benhammou ${ }^{(\mathrm{a})}$, Younes Abouliatim ${ }^{(\mathrm{a})}$, \\ Youssef El Hafiane ${ }^{(\mathrm{f})}$, Hassan Hannache ${ }^{(\mathrm{b})}$, Marc Birot ${ }^{(\mathrm{c})}$, René Pailler ${ }^{(\mathrm{d})}$, \\ Roger Naslain ${ }^{(\mathrm{d})}$
}

(a) Laboratoire Matériaux, Procédés et environnement, École Nationale des Sciences Appliquées, B.P. 6346000 Safi, Morocco

(b) Laboratoire des Matériaux Thermostructuraux, Faculté des Sciences Ben M'sik, B.P. 7955 Casablanca, Morocco

(c) Université de Bordeaux, Institut des Sciences Moléculaires, CNRS-UMR 5255, 351 cours de la Libération, F-33405 Talence, France

(d) Université Bordeaux/CNRS/CEA/SAFRAN, Laboratoire des Composites Thermostructuraux (LCTS), 3 allée de la Boétie, F-33600 Pessac, France

(e) Department of Materials Science and Nanoengineering, University of Mohamed VI Polytechnic, Lot 660-Hay Moulay Rachid, 43150, Ben Guerir, Morocco

(f) Institute of Research on Ceramics, IRCER, UMR CNRS 7315, Centre Européen de La Céramique, Université de Limoges, 12 Avenue Atlantis, 87068, Limoges Cedex, France

\begin{abstract}
Within the Moroccan natural resources valorisation scheme, new adsorbents have been prepared from oil shale by chemical and physical activation processes. The activation process the authors have developed in this study give effective adsorbent materials. In view of the physico-chemical properties of these materials and application to the treatment of water loaded with a metal ( $\mathrm{Cr}^{6+}$ ion) or organic (methylene blue (MB)) pollutant, it is concluded that the chemical activation process of oil shale at low temperature $\left(250{ }^{\circ} \mathrm{C}\right)$ affords the best material. The material's yield is good in comparison with the physical activation at the same temperature and the process is energy saving differently from that at $450^{\circ} \mathrm{C}$. Moreover, the chemical activation of oil shale with phosphoric acid at $250{ }^{\circ} \mathrm{C}$ produces a material with a good yield (about 70\%), a high specific surface area (approximately $600 \mathrm{~m}^{2} / \mathrm{g}$ ) and a highly porous structure, which gives it a high retention of methylene blue and the $\mathrm{Cr}^{6+}$ ion.
\end{abstract}

Keywords: Moroccan oil shale, adsorbents, activation process, specific surface area.

\footnotetext{
* Corresponding author: e-mailkrimabou@hotmail.com \&a.abourriche@uca.ma
} 


\section{Introduction}

Oil shale was considered for a long time an economic hope, hence programs to operate oil shale as an energy source were launched by Scotland, Australia, France and China [1-4]. These programs eventually demonstrated that oil shale was far from being a substitute for oil because of high cost and noncompetitiveness against conventional petroleum. However, the burnt oil shale has some potential for the production of cement, calcium, alumina, pitches, carbon adsorbents, zeolites, carbon fibres and other chemicals [5-12].

Otherwise, activated carbon is an efficient adsorbent for remediation of waste waters. Therefore, researches have focused on the development of activated carbons from industrial or agricultural wastes such as apricot stones $[13,14]$, sawdust [15], bagasse [16, 17], globe artichoke leaves [18], bark of pomegranate [19], molasses [20], or nut shells [21]. Different activation methods are used in order to obtain a material with adsorbing properties.

Generally, there are two methods of preparing activated carbons: physical activation and chemical activation. Physical activation is a two-step process that starts with the carbonization of materials followed by the activation of the resulting char in inert $\left(\mathrm{Ar}\right.$ or $\left.\mathrm{N}_{2}\right)$ or oxidizing atmosphere $\left(\mathrm{CO}_{2}\right.$ or $\left.\mathrm{O}_{2}\right)$ in the temperature range of $600-1000{ }^{\circ} \mathrm{C}$ [22]. A study by Yang et al. [23] demonstrated that activated carbons prepared by the physical heating process using agents such as steam, $\mathrm{CO}_{2}$ and a mixture of steam- $\mathrm{CO}_{2}$ gave a high Brunauer-Emmett-Teller (BET) surface area. On the other hand, chemical activation using phosphoric acid $\left(\mathrm{H}_{3} \mathrm{PO}_{4}\right)$ is widely used for lingocellulosic precursors $[24,25]$. It can promote the separation between cellulose and lignin degradation agent and units of cellulose [26]. In addition to its role as an inhibitor of carbon oxidation, phosphoric acid plays a catalytic role in the dehydration reaction. Because of its good curing properties, the acid also promotes the development of a three-dimensional structure with high porosity and specific surface area.

We are presently carrying out researches to find new applications of Moroccan abundant natural resources. The present work aimed to investigate whether Moroccan oil shale behaved as an efficient resource to produce new adsorbent materials, and to test the obtained adsorbents for their ability to retain the $\mathrm{Cr}^{6+}$ ion and methylene blue (MB) dye commonly employed as indicators to evaluate adsorbents, and, finally, to compare their adsorption capacities with those of some other materials [27, 28]. In this paper, we discuss the experimental results obtained for adsorbent materials prepared using the chemical or physical activation process. 


\section{Experimental}

\subsection{Materials}

The oil shale used in this work was from the Tarfaya deposit located in the south of Morocco. This deposit consists of several layers subdivided into sublayers, each containing a different amount of organic matter. The samples were obtained from the $\mathrm{R}_{3}$ sub-layer, which is characterized by a high content of organic matter, as seen from Table 1 [29]. The chemical composition of the $\mathrm{R}_{3}$ sub-layer is given in Table 2 [30].

The carbonate-free oil shale $(\mathrm{RH})$ was obtained by the reaction of carbonates with $\mathrm{HCl}[31,32]$. The powdered $\mathrm{R}_{3}$ shale $(20 \mathrm{~g}$, grain size $0.063-$ $0.08 \mathrm{~mm})$ and $80 \mathrm{~mL}$ of concentrated $\mathrm{HCl}(7 \mathrm{M})$ were introduced into an Erlenmeyer. The mixture was then subjected to magnetic stirring for $4 \mathrm{~h}$. The formed $\mathrm{CO}_{2}$ was trapped by bubbling in a solution of barium hydroxide. After filtration, the solid residue (referred to as $\mathrm{RH}$ ) was washed carefully with distilled water, dried at $100{ }^{\circ} \mathrm{C}$ and stocked in a sealed plastic bag. Our choice of the carbonate-free oil shale as a precursor for preparing activated carbon was made based on the results obtained in a previous work [33].

Table 1. Composition of the $R_{3}$ sub-layer [29]

\begin{tabular}{|l|c|}
\hline Component & $\mathrm{wt} \%$ \\
\hline Carbonates & 70.0 \\
Kerogen & 20.0 \\
Silicates & 7.1 \\
Pyrite & 1.0 \\
Bitumen & 0.9 \\
\hline
\end{tabular}

Table 2. Characteristics of the $R_{3}$ sub-layer [30]

\begin{tabular}{|l|c|}
\hline Characteristic & $\mathrm{wt} \%$ \\
\hline Moisture & 17.5 \\
Ashes & 54.9 \\
Volatile & 40.2 \\
Organic carbon & 11.3 \\
\hline
\end{tabular}




\subsection{Apparatus}

\subsubsection{Preparation of adsorbents}

\subsubsection{Physical activation process}

The thermal process was based on the calcination of $\mathrm{RH}$ in oxidant atmosphere (air) in a muffle furnace at different temperatures with the five values between 200 and $550{ }^{\circ} \mathrm{C}$, the treatment time was $1 \mathrm{~h}$.

The materials obtained after heat treatment were labelled RHA200, RHA250, RHA350, RHA450 and RHA550.

\subsubsection{Chemical activation process}

The chemical activation of RH was conducted under the following experimental conditions: $10 \mathrm{~g}$ of $\mathrm{RH}$ was added to $20 \mathrm{~g}$ of dilute phosphoric acid $80 \%$ in distilled water (acid \% in the mixture). These ingredients were well mixed to a paste that was introduced into a basket and then heat-treated for $2 \mathrm{~h}$ in air in a horizontal electric furnace. Processing temperatures were 250, 350, 450 and $550{ }^{\circ} \mathrm{C}$. The obtained materials labelled RHP250, RHP350, RHP450 and RHP550 were washed with distilled water using a Soxhlet apparatus for $24 \mathrm{~h}$, to remove the excess of phosphoric acid, then dried in an oven at $120{ }^{\circ} \mathrm{C}$ and weighed to determine the yield of carbonization.

\subsubsection{Adsorption tests}

\subsubsection{Methylene blue adsorption test}

The kinetic curves showing the variation of the adsorption efficiency vs time on a methylene blue aqueous solution containing $20 \mathrm{mg} / \mathrm{L}$ of MB were obtained at room temperature. Typically, the RHA or RHP material (40 mg) of particle size less than $100 \mu \mathrm{m}$ was dispersed in $200 \mathrm{~mL}$ of solution. The suspension was stirred continuously during all handlings to ensure a better contact between the pollutant in solution and the active sites of the adsorbent.

\subsubsection{2. $\mathrm{Cr}^{6+}$ ion adsorption test}

The adsorption tests were carried out in hydrochloric acid medium $(\mathrm{pH}=2.5)$ on a potassium dichromate aqueous solution containing $10 \mathrm{mg} / \mathrm{L}$ of $\mathrm{Cr}^{6+}$ ion. The RHA or RHP material (100 mg) of particle size less than $100 \mu \mathrm{m}$ was dispersed in $200 \mathrm{~mL}$ of solution. The suspension was stirred continuously during all handlings.

\subsection{Characterization of techniques}

The X-ray photoelectron spectroscopy (XPS) analysis was carried out in an Escalab VG220i-XL apparatus.

The electron probe X-ray microanalysis (EPMA) was performed with a Cameca SX100 apparatus. 
The concentration of MB was measured with a UV-Visible Spectrophotometer (Perkin Elmer Lambda 2), characterized by wavelengths from 190 to $1100 \mathrm{~nm}$. The UV-visible spectrum of $\mathrm{MB}$ had a maximum absorption band $\lambda_{\text {max }}=664 \mathrm{~nm}$.

The concentration of the $\mathrm{Cr}^{6+}$ ion was estimated with a GBC 908 PBMT flame atomic absorption spectrophotometer.

Infrared (IR) spectra were recorded between 400 and $4000 \mathrm{~cm}^{-1}$ with a Nicolet 205 FT-IR Spectrometer by summing 32 scans at $2 \mathrm{~cm}^{-1}$ resolution. Pellets were prepared by dispersing $2 \mathrm{mg}$ of sample into $198 \mathrm{mg}$ of $\mathrm{KBr}$.

Thermogravimetric analysis/differential thermal analysis (TGA/DTA) was performed with a Perkin-Elmer TGS-2 Thermogravimetric Analyzer under high purity argon flow $\left(40 \mathrm{~mL} \cdot \mathrm{min}^{-1}\right)$. Samples of about $12 \mathrm{mg}$ were heated from 50 to $950{ }^{\circ} \mathrm{C}$ at a heating rate of $5{ }^{\circ} \mathrm{C} \cdot \mathrm{min}^{-1}$.

The specific surface areas of carbon materials were measured by nitrogen adsorption at $77 \mathrm{~K}$ with a Micromeritics FlowSorb II 2300 instrument using the BET method. The samples were outgassed at $160{ }^{\circ} \mathrm{C}$ for $24 \mathrm{~h}$ before analysis.

Scanning electron microscopy (SEM) micrographs were taken with a Hitachi TM-1000 Microscope. Fragments of about $0.5 \mathrm{~cm}^{2}$ cut from the corresponding samples were mounted on a carbon tab, which ensured a good conductivity. A thin layer of gold-palladium was sputtered prior to analysis.

\section{Results and discussion}

\subsection{Characterization of sample $\mathrm{RH}$}

The results of XPS analysis given in Table 3 show that the contents of elements carbon, nitrogen, sulfur, aluminium and silicon identified in $\mathrm{RH}$ have significantly increased. At the same time, the contents of oxygen and calcium have decreased, which gives evidence of that the attack on the rough rock $\mathrm{R}_{3}$ by hydrochloric acid allowed dissolving completely the carbonate. These results were confirmed by EPMA analysis (Fig. 1). Moreover, EPMA revealed the presence of other elements at greater depths that could not be detected by XPS.

The analysis of diffraction pattern RX (Fig. 2) shows that the RH mineral matrix consists essentially of quartz. Pyrite and kaolinite are also present, but in minor amounts.

The SEM analysis reveals RH to be a microporous material with a uniform distribution of the grain size of the order of $1 \mu \mathrm{m}$. The resulting value of $S_{\mathrm{BET}}$ is of the order of $13 \mathrm{~m}^{2} \cdot \mathrm{g}^{-1}$. 
Table 3. XPS analysis of starting materials, atomic \%

\begin{tabular}{|l|c|c|}
\hline Element & $\mathrm{R}_{3}$ & $\mathrm{RH}$ \\
\hline $\mathrm{Fe}(2 \mathrm{p} 3)$ & 0.2 & 0.1 \\
$\mathrm{O}(1 \mathrm{~s})$ & 37.5 & 26.9 \\
$\mathrm{~N}(1 \mathrm{~s})$ & 0.4 & 1.3 \\
$\mathrm{C}(1 \mathrm{~s})$ & 43.4 & 56.0 \\
$\mathrm{Cl}(2 \mathrm{p})$ & 2.5 & 0.4 \\
$\mathrm{~S}(2 \mathrm{p})$ & 0.8 & 2.1 \\
$\mathrm{Al}(2 \mathrm{~s})$ & 2.4 & 3.7 \\
$\mathrm{Si}(2 \mathrm{p})$ & 3.2 & 8.2 \\
$\mathrm{Ca}(2 \mathrm{p})$ & 9.3 & - \\
$\mathrm{Mg}$ & 0.1 & - \\
$\mathrm{Na}$ & 0.2 & - \\
\hline
\end{tabular}

(a)

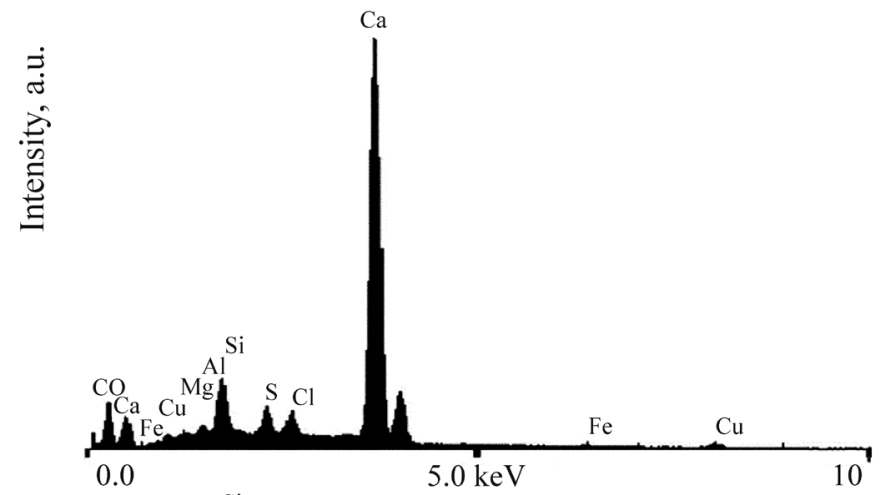

(b)

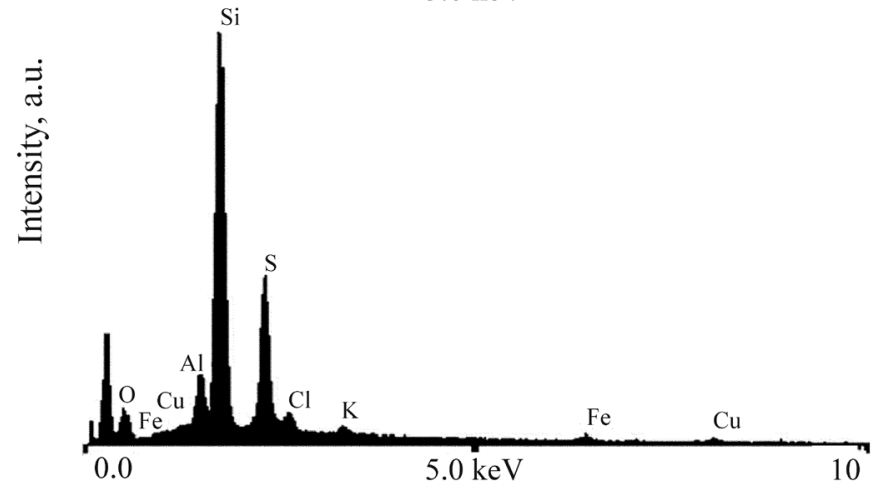

Fig. 1. Energy dispersive X-ray (EDX) spectra of samples: (a) R; (b) RH. 


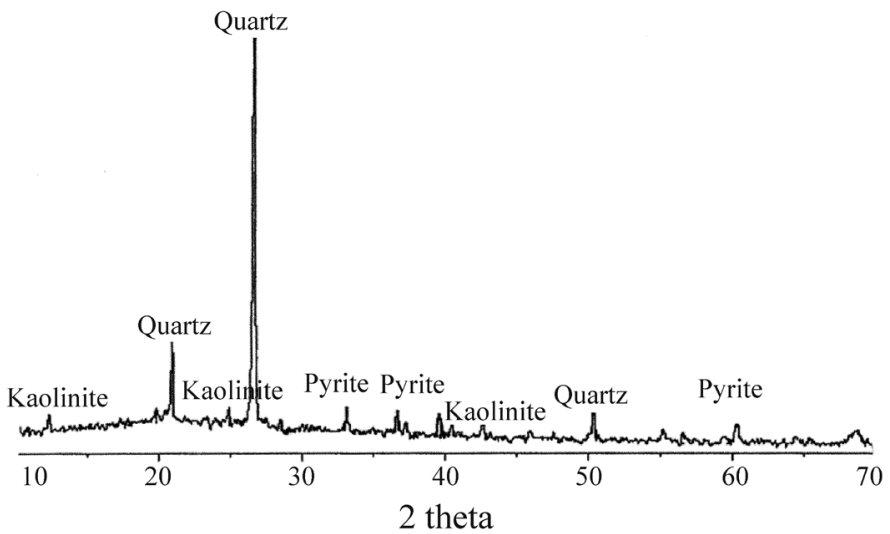

Fig. 2. XRD of sample RH.

The results of TGA/DTA (Fig. 3) demonstrate that $\mathrm{RH}$ undergoes a continuous mass loss at temperatures from about 150 to $535^{\circ} \mathrm{C}$, which reflects the elimination of groups and chains resulting from the degradation of organic matter by air oxidation. This oxidation results in an exothermic peak on the DTA curve with a maximum at $260{ }^{\circ} \mathrm{C}$. The DTA curve also displays an endothermic peak whose maximum is situated around $480{ }^{\circ} \mathrm{C}$. This peak can be due to the processing of organic carbon, or the oxidation or decomposition of the mineral matter present in $\mathrm{RH}$.

(a)

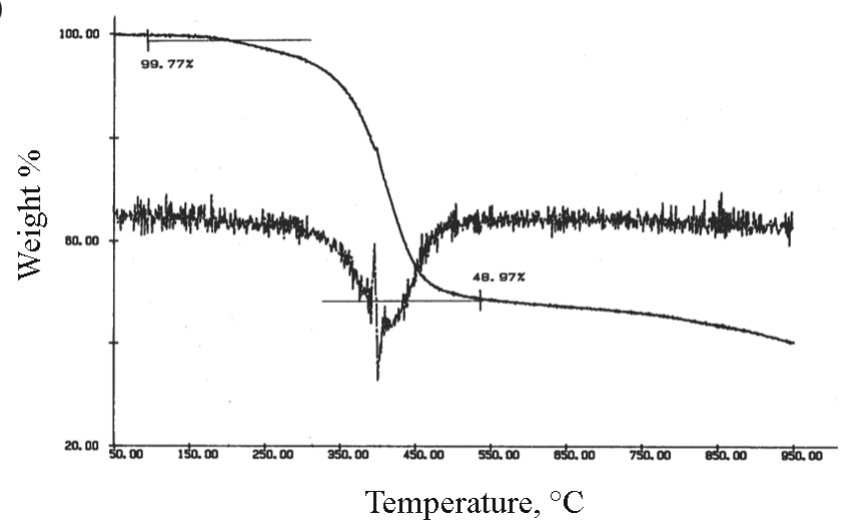


(b)

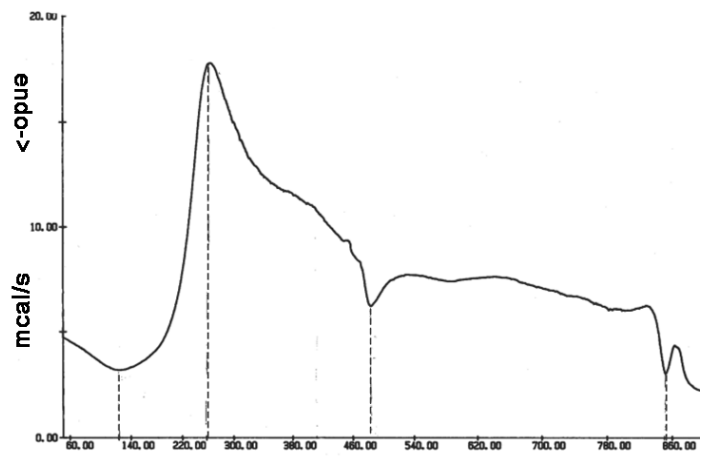

Temperature, ${ }^{\circ} \mathrm{C}$

Fig. 3. Thermogravimetric curves of sample RH: (a) TGA; (b) DTA.

\subsection{Variation of the yield of obtained materials with treatment temperature}

We determined the yield $R$ of the obtained materials by the following equation:

$$
R=\frac{m_{\mathrm{f}}}{m_{\mathrm{i}}} \times 100,
$$

where $m_{\mathrm{i}}$ is the mass of RH initially introduced into the furnace and $m_{\mathrm{f}}$ is the mass of adsorbent materials prepared.

The histogram in Figure 4 shows the variation of the yields of adsorbent materials obtained at different temperatures. Low yields result from a severe oxidation of the organic matter of $\mathrm{RH}$ by oxygen in air. This promotes a complete degradation of kerogen even at low temperature, to end at $550{ }^{\circ} \mathrm{C}$,

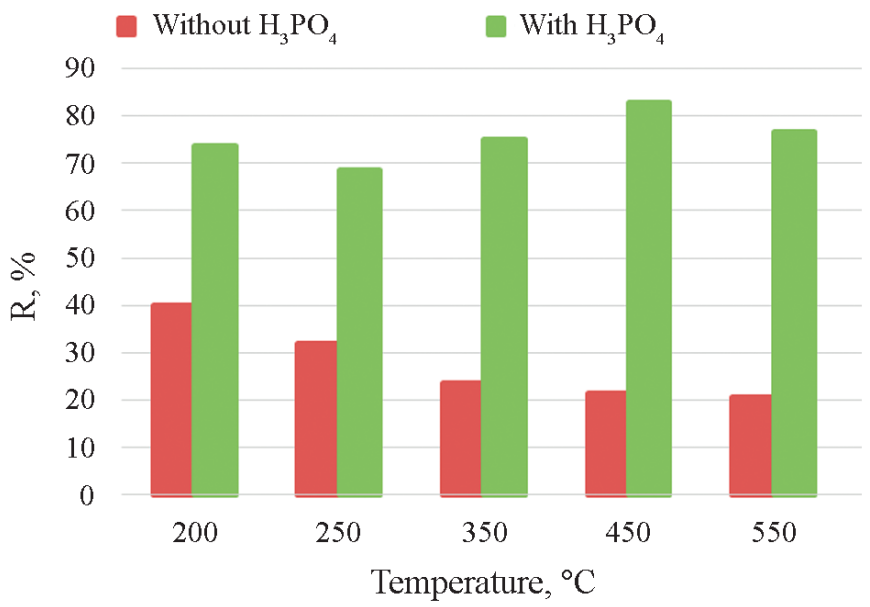

Fig. 4. Variation in the yield of adsorbent materials obtained at different temperatures. 
with ash completely devoid of organic matter. The ash amount of $22 \%$ at $550{ }^{\circ} \mathrm{C}$ gives evidence of that $\mathrm{RH}$ was composed of about $78 \%$ of organic matter and $22 \%$ of mineral matter.

The yields of RHP materials at $450{ }^{\circ} \mathrm{C}$ are significantly higher than those of RHA adsorbents. This emphasizes the crosslinking effect of phosphoric acid which protects the carbon skeleton of oil shale even at high temperature $\left(550^{\circ} \mathrm{C}\right)$. One can also note that the yield of $\mathrm{RH}$ is minimum at $250^{\circ} \mathrm{C}$ and reaches its maximum at $450{ }^{\circ} \mathrm{C}$. We can therefore say that the maximum loss of RH by the oxidation of organic matter and degassing occurred at $250{ }^{\circ} \mathrm{C}$, but this loss was still small compared to what was observed during its heat treatment in air only. This increase in RH yield can be explained by the rearrangement and crosslinking of organic material, which is certainly accompanied by the inclusion of heteroatoms such as oxygen and phosphorus. When the temperature exceeds $450{ }^{\circ} \mathrm{C}$, the activation efficiency drops again; this decrease may be due to the oxidation of organic matter and the release of certain gases such as $\mathrm{CO}_{2}$.

\subsection{Effect of activation temperature on adsorption capacity}

\subsubsection{Physical activation process}

The curves in Figure 5 show the variation of the adsorption performance of RHA samples as a function of time. In the case of MB (Fig. 5a) the saturation of different samples was reached after almost $2 \mathrm{~h}$ of contact between the adsorbent and the adsorbate. The adsorption of the $\mathrm{Cr}^{6+}$ ion is instantaneous and saturation of different materials takes place after almost $1 \mathrm{~h}$ of contact between the adsorbent and the adsorbate, except in the case of RHA200 treated in air at $200{ }^{\circ} \mathrm{C}$, whose adsorption-desorption equilibrium is reached around $3 \mathrm{~h}$ of contact. It is probable that the stabilization of the organic matter of RH at this temperature has not yet occurred.

(a)

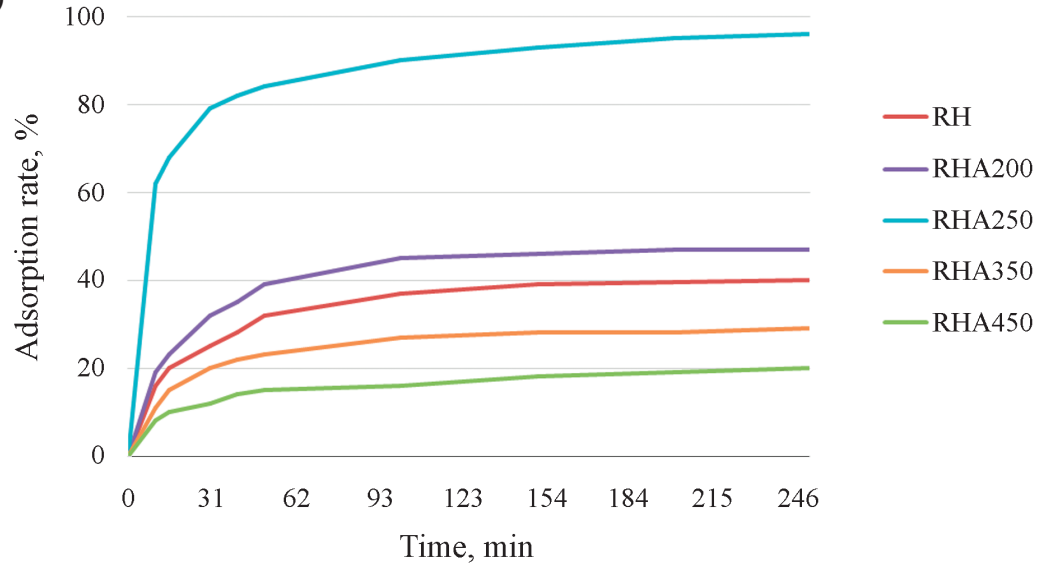


(b)

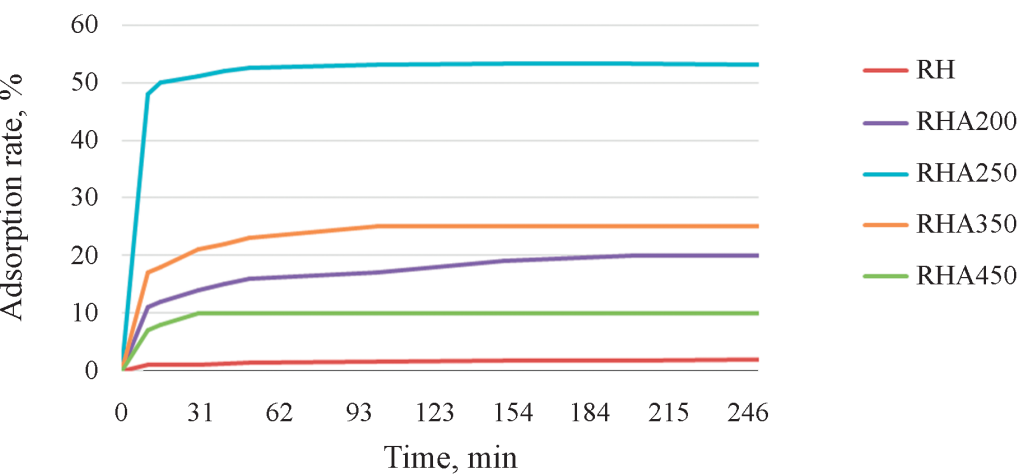

Fig. 5. Adsorption kinetics of (a) methylene blue and (b) $\mathrm{Cr}^{6+}$ ion onto RHA adsorbents obtained by physical activation.

The adsorption capacities of the different materials obtained by the physical activation of RH are given in Table 4. It can be seen from the table that RHA250 has the highest adsorption capacity. The adsorption performance of materials decreases as the treatment temperature increases. The adsorption efficiency of RHA250 can be linked to the existence of surface functions created at that temperature (the $\mathrm{C}=\mathrm{O}$ band around $1720 \mathrm{~cm}^{-1}$ which is present in the IR spectrum of RHA250 is hardly observed in those of samples RHA350 and RHA450, see section 3.4.3.). In consequence, the temperature value of $250{ }^{\circ} \mathrm{C}$ is chosen as optimal temperature for the physical activation of $\mathrm{RH}$.

Table 4. Effect of activation temperature on the adsorption capacity of adsorbents obtained by physical activation

\begin{tabular}{|l|c|c|}
\hline \multirow{2}{*}{ Sample } & \multicolumn{2}{|c|}{ Adsorption capacity, mg/g } \\
\cline { 2 - 3 } & Methylene blue & $\mathrm{Cr}^{6+}$ ion \\
\hline RH & 15.4 & 1.5 \\
RHA200 & 17.2 & 5.1 \\
RHA250 & 37.0 & 8.4 \\
RHA350 & 10.1 & 6.4 \\
RHA450 & 6.8 & 5.4 \\
RHA550 & 3.1 & 1.8 \\
\hline
\end{tabular}

$\mathrm{RH}$ - carbonate-free oil shale

RHA200, etc. - sample activated physically at $200{ }^{\circ} \mathrm{C}, 250^{\circ} \mathrm{C}, 350^{\circ} \mathrm{C}, 450{ }^{\circ} \mathrm{C}$ and $550{ }^{\circ} \mathrm{C}$ 


\subsubsection{Chemical activation process}

The adsorption tests of RHP samples were performed under the same conditions as for RHA materials. Figure 6 shows the variation of the adsorption yield of the adsorbent as a function of the time of contact with the adsorbate. To highlight the effect of phosphoric acid on the process, we also constructed the curve for the RHA250 sample treated at $250{ }^{\circ} \mathrm{C}$ in air only in order to compare the curves of the two materials treated at $250{ }^{\circ} \mathrm{C}$ with and without phosphoric acid. Therefore, in addition to the gain in the yield of pyrolysis, which is significantly higher than that obtained in the case of physical activation, the material chemically activated with phosphoric acid has surface properties that give it a greater capacity for adsorption of the $\mathrm{Cr}^{6+}$ ion and $\mathrm{MB}$. This enables one to assume that phosphoric acid acts as a dehydrating and crosslinking agent even at a carbonization temperature as low as $250^{\circ} \mathrm{C}$. Worthy of note is also the difference in adsorption performance between the materials. Indeed, adsorption is almost instantaneous for RHP450, but for RHP250 it is much slower. This is probably due to surface conditions, the materials treated at $450{ }^{\circ} \mathrm{C}$ being much more porous than those obtained at $250{ }^{\circ} \mathrm{C}$ (Table 5).

(a)

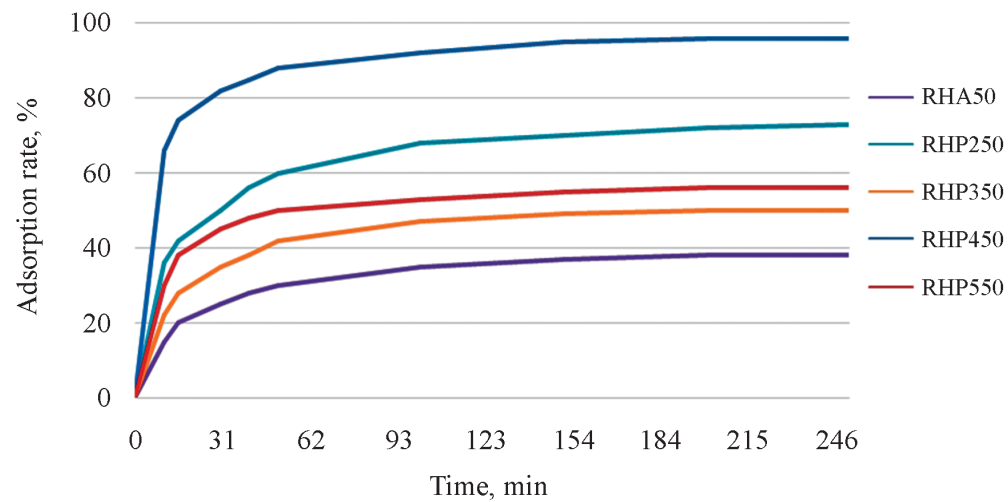

(b)

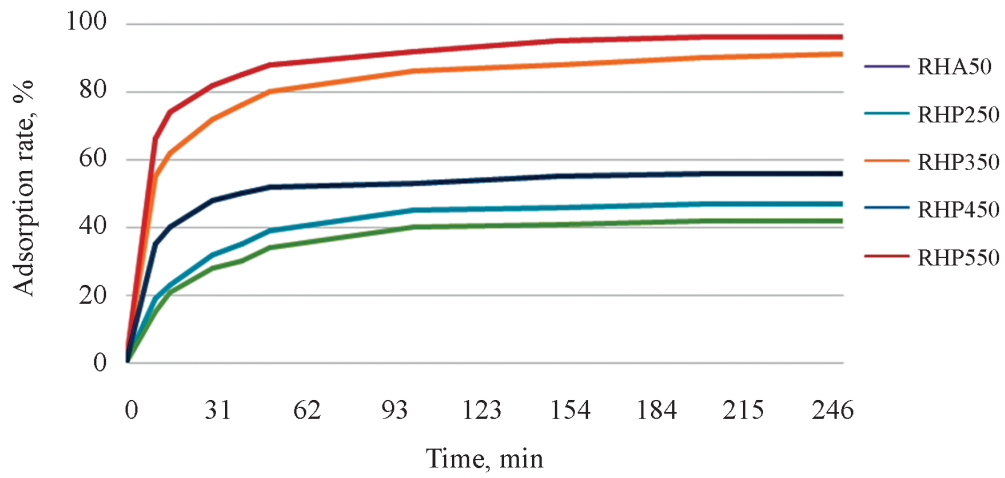

Fig. 6. Adsorption kinetics of (a) methylene blue and (b) $\mathrm{Cr}^{0+}$ ion onto RHP adsorbents obtained by chemical activation. 
Table 5. Specific surface area of samples

\begin{tabular}{|l|c|}
\hline Sample & $S_{\text {BET }}, \mathrm{m}^{2} / \mathrm{g}$ \\
\hline RH & 13 \\
RHA250 & 84 \\
RHP250 & 587 \\
RHP450 & 486 \\
\hline
\end{tabular}

RH - carbonate-free oil shale

RHA250 - sample activated physically at $250{ }^{\circ} \mathrm{C}$

RHP250, RHP450 - sample activated chemically at $250^{\circ} \mathrm{C}$ and $450^{\circ} \mathrm{C}$

From Figure 6 it can be seen that the curves for RHP350 are not regular compared to other samples. This can be explained by the instability of organic material at this temperature, which leads to the reorganization of the carbon skeleton following the oxidation reactions taking place at a temperature of 250 ${ }^{\circ} \mathrm{C}$ or insertion of heteroatoms such as phosphorus or oxygen in the material structure. The low adsorption efficiency observed for the RHP550 adsorbent can be related to the deterioration of surface properties (surface features or porosity) when the temperature exceeds $450{ }^{\circ} \mathrm{C}$, because the oxidation of organic material takes generally place between 450 and $550{ }^{\circ} \mathrm{C}$ (Table 6).

Table 6 summarizes the variations in the adsorption capacity of materials as a function of treatment temperature. RHP250 and RHP450 treated at $250{ }^{\circ} \mathrm{C}$ and $450{ }^{\circ} \mathrm{C}$, respectively, possess the best adsorption capacities. The materials treated at the other temperatures are less effective with respect to the adsorption of $\mathrm{MB}$ and the $\mathrm{Cr}^{6+}$ ion.

Comparison of the adsorption capacities of materials treated at $250^{\circ} \mathrm{C}$ with and without phosphoric acid demonstrates that for the $\mathrm{Cr}^{6+}$ ion the phosphoric acid-triggered chemical activation allowed increasing the adsorption capacity from $8.4 \mathrm{mg} / \mathrm{g}$ for RHA250 to $15 \mathrm{mg} / \mathrm{g}$ for RHP250 (Table 6).

Finally, RHA250, RHP250 and RHP450, being the best adsorbents, were further characterized.

Table 6. Effect of activation temperature on the adsorption capacity of adsorbents obtained by phosphoric acid-triggered chemical activation

\begin{tabular}{|l|c|c|}
\hline \multirow{2}{*}{ Sample } & \multicolumn{2}{|c|}{ Adsorption capacity, $\mathrm{mg} / \mathrm{g}$} \\
\cline { 2 - 3 } & Methylene blue & $\mathrm{Cr}^{6+}$ ion \\
\hline RH & 15.4 & 1.5 \\
RHP250 & 91.6 & 15.0 \\
RHP350 & 59.3 & 9.3 \\
RHP450 & 102.8 & 16.4 \\
RHP550 & 73.0 & 10.8 \\
\hline
\end{tabular}

$\mathrm{RH}$ - carbonate-free oil shale

RHP250, etc. - sample activated chemically at $250{ }^{\circ} \mathrm{C}, 350{ }^{\circ} \mathrm{C}, 450{ }^{\circ} \mathrm{C}$ and $550{ }^{\circ} \mathrm{C}$ 


\subsection{Characterization of obtained adsorbents}

\subsubsection{Specific surface areas}

The specific surface areas of the obtained adsorbents (Table 5) reflect the effect of phosphoric acid on the development of porosity of the chemically activated material. Physical activation also contributed to the development of porosity and increase of the surface area of RHA carbons, but this area was very low compared with that formed at the same temperature by chemical activation. Similarly, the low yields of adsorbents obtained in the physical activation allow us to conclude that the acid-facilitated chemical activation is a more suitable method for preparing activated carbons from oil shale.

\subsubsection{SEM}

The SEM of adsorbent materials was performed under the same conditions as above in order to compare their morphological appearances. The micrographs obtained (Fig. 7) reveal RHP250 and RHP450 samples to have a maximum developed porosity, with the microporous structure being uniformly distributed throughout the materials. This confirms the results obtained by the BET method. Sample RHA250 has also a porous structure containing micropores, but these are less abundant than in RHP250 and RHP450.

(a)

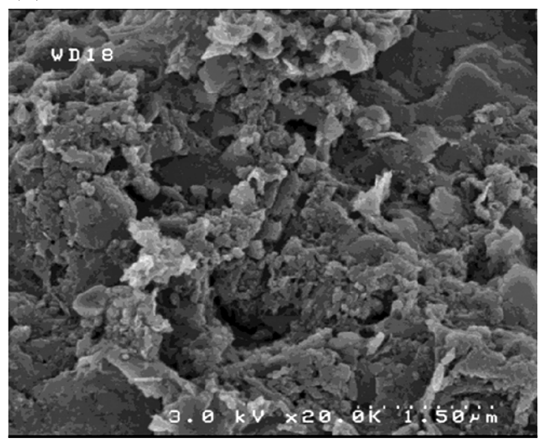

(c)

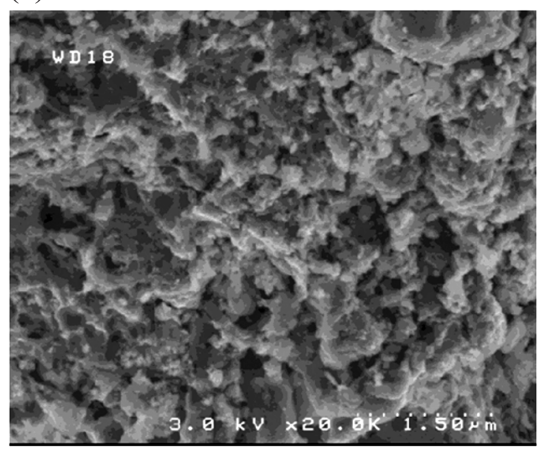

(b)

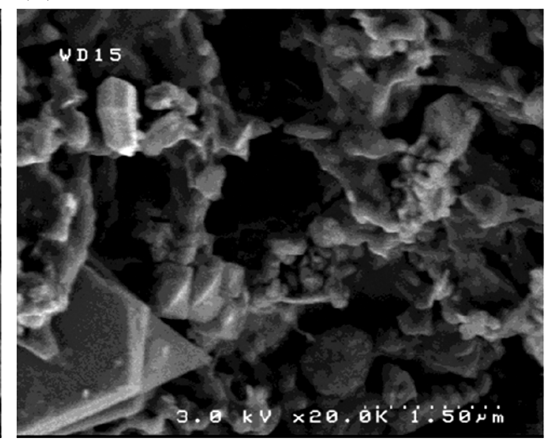

(d)

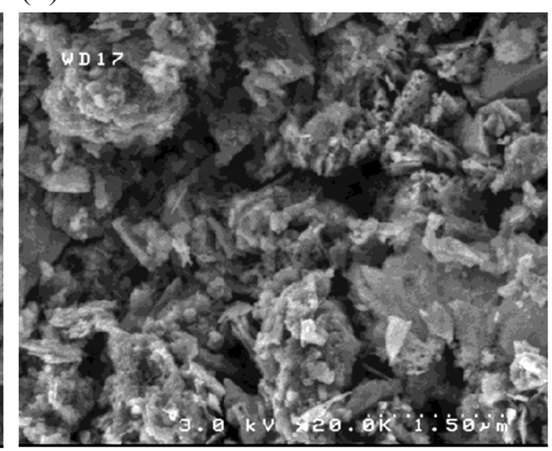

Fig. 7. SEM micrographs of obtained adsorbents: (a) RH; (b) RHA250; (c) RHP250; (d) RHP450. 


\subsubsection{IR}

The above adsorbents were also characterized by IR spectroscopy (Fig. 8). All of the IR spectra of the samples recorded are very similar to those obtained earlier by Christy et al. [34] and Aboulkas et al. [35]. These spectra allow making the following remarks: (i) There takes place a total disappearance of characteristic bands of $\mathrm{C}-\mathrm{H}$ bonds (methyl and methylene groups) in the spectra of samples RHA250 and RHP450, while these are still present in those of sample RHP250. This confirms the important role of phosphoric acid in protecting organic matter against oxidation. (ii) The band around $1720 \mathrm{~cm}^{-1}$, which is characteristic of $\mathrm{C}=\mathrm{O}$ aromatic esters, is well defined in the IR spectra of samples RHP250 and RHA250, while in that of RHP450 it is a simple shoulder. This shows that the oxidation of organic material and grafting of oxygen on the carbon atoms at the surface take place at low temperature $\left(250^{\circ} \mathrm{C}\right)$. (iii) The two bands of low intensity around $2400 \mathrm{~cm}^{-1}$, which are characteristic of carboxyl groups, are frequently observed in the IR spectra of activated carbons. These bands are intense in the IR spectra of samples RHP450 and RHP250, but are weak in that of RHA250.

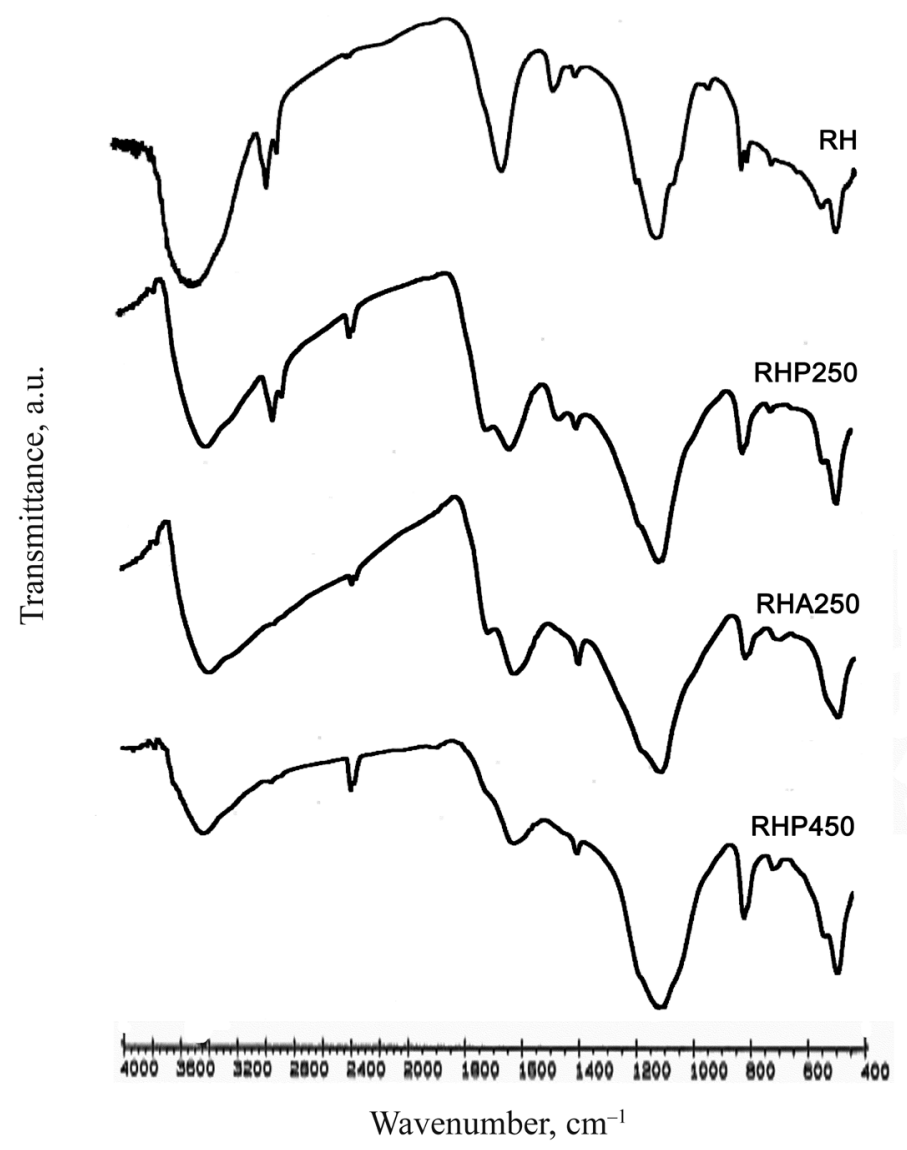

Fig. 8. IR spectra of obtained adsorbents. 


\subsubsection{Adsorption isotherms}

In order to describe the performance of the obtained adsorbents using MB, two adsorption models, Langmuir and Freundlich, were used [36, 37].

The Langmuir and Freundlich equations are expressed respectively as follows [38]:

$$
\begin{gathered}
1 / Q_{e}=1 / Q_{\text {max }}+1 /\left(k Q_{\max } \cdot C_{e}\right), \\
\log Q_{e}=\log K_{f}+n \cdot \log C_{e},
\end{gathered}
$$

where

$Q_{e}$ is the adsorption capacity at equilibrium, $\mathrm{mg} / \mathrm{g}$;

$Q_{\max }$ is the maximal adsorption capacity, $\mathrm{mg} / \mathrm{g}$;

$C_{e}$ is the equilibrium concentration of solute in the aqueous phase, $\mathrm{mg} / \mathrm{L}$;

$k$ is the thermodynamic adsorption constant, $\mathrm{L} / \mathrm{mg}$;

$K_{f}$ and $n$ are constants of the Freundlich model linked to the adsorption capacity and the intensity, respectively.

The isotherm constants and coefficients of Langmuir and Freundlich equations are presented in Table 7 . From the table it can be seen that sample RHP250 has a maximum surface adsorption. The relatively low values in the case of sample RHA250 confirm the important role of phosphoric acid in protecting organic matter and developing the materials porosity. One can also note that the adsorption efficiency of our sample RHP250 is higher than that of adsorbents elaborated from Moroccan Timahdit oil shale by chemical activation [39]. Obtained from Langmuir and Freundlich models, the values of maximal adsorption capacity, in terms of MB, are 667 and $47.4 \mathrm{mg} / \mathrm{g}$, respectively.

Table 7. Parameters of Langmuir and Freundlich equations for adsorption of methylene blue onto different samples

\begin{tabular}{|l|rcccccc|}
\hline \multirow{2}{*}{ Sample } & \multicolumn{3}{|c}{ Langmuir } & \multicolumn{3}{c|}{ Freundlich } \\
\cline { 2 - 7 } & $Q_{\max }, \mathrm{mg} / \mathrm{g}$ & $b$ & $R^{2}$ & $k_{f} \mathrm{mg} / \mathrm{g}$ & $n$ & $R^{2}$ \\
\hline RHA250 & 212 & 0.076 & 0.99 & 25.32 & 0.516 & 0.97 \\
RHP250 & 667 & 0.067 & 0.99 & 47.4 & 0.71 & 0.99 \\
RHP450 & 333 & 0.030 & 0.99 & 14.94 & 0.69 & 0.99 \\
\hline
\end{tabular}

RHA250 - sample activated physically at $250{ }^{\circ} \mathrm{C}$

RHP250, RHP450 - sample activated chemically at $250{ }^{\circ} \mathrm{C}$ and $450{ }^{\circ} \mathrm{C}$ 
Table 8. Langmuir constant $Q_{\max }$ for adsorption of methylene blue

\begin{tabular}{|l|c|c|}
\hline Sample & $Q_{\max }, \mathrm{mg} / \mathrm{g}$ & Reference \\
\hline MS750V & 435 & {$[20]$} \\
SCB & 258 & {$[40]$} \\
EZKA & 435 & {$[41]$} \\
CAGO & 403 & {$[42]$} \\
YHA300 $(2.5 \mathrm{~h})$ & 175 & {$[43]$} \\
RHP250 & 667 & Present work \\
\hline
\end{tabular}

RHP250 - sample activated chemically at $250{ }^{\circ} \mathrm{C}$

For comparison, the adsorption capacities of other activated carbons reported in the literature are also given in Table 8 , along with that of adsorbent RHP250 obtained in the present study. The table reveals the latter to have a higher adsorption efficiency than that of other activated carbons.

\section{Conclusions}

Within the framework of the development of Moroccan natural resources, we have carried out a study on Tarfaya oil shale in order to prepare new adsorbents. The following conclusions can be drawn from the present investigation on the comparative studies of chemical and physical activation processes:

The adsorption capacity of adsorbents obtained by chemical activation is significantly higher than that obtained by physical activation.

Tarfaya oil shale can be a suitable adsorbent for the removal of metals or organics from water and waste waters as both the adsorption kinetics and capacity are high.

Adsorbent materials produced in this work possess a high adsorption capacity compared to other adsorbents reported in the literature.

The phosphoric acid-induced chemical activation of oil shale at low temperature $\left(250{ }^{\circ} \mathrm{C}\right)$ produces a material with a good yield (about $70 \%$ ), a high specific surface area (approximately $600 \mathrm{~m}^{2} / \mathrm{g}$ ) and a highly porous structure, which gives it a high retention of methylene blue and the $\mathrm{Cr}^{6+}$ ion.

\section{REFERENCES}

1. Oil shales of the world. Their origin, occurrence, and exploitation. Energ. Explor. Exploit., 1990, 8(6), 457-457.

2. Väizene, V., Valgma, I., Iskül, R., Kolats, M., Nurme, M., Karu, V. High selective oil shale mining. Oil Shale, 2013, 30(2S), 305-325. 
3. Ranney, M. W. Oil Shale and Tar Sands Technology: Recent Developments. Park Ridge, New Jersey, USA, 1979.

4. Van Graas, G., de Leeuw, J. W., Schenck, P. A., Haverkamp, J. Kerogen of Toarcian shales of the Paris Basin. A study of its maturation by flash pyrolysis techniques. Geochim. Cosmochim. Ac., 1981, 45(12), 2465-2474.

5. Velts, O., Uibu, M., Kallas, J., Kuusik, R. Waste oil shale ash as a novel source of calcium for precipitated calcium carbonate: Carbonation mechanism, modeling, and product characterization. J. Hazard. Mater., 2011, 195, 139-146.

6. Miao, L., Ji, G., Gao, G., Li, G., Gan, S. Extraction of alumina powders from the oil shale ash by hydrometallurgical technology. Powder Technol., 2011, 207(1-3), 343-347.

7. Sun, T., Liu, L. L., Wan, L. L., Zhang, Y. P. Effect of silicon dose on preparation and coagulation performance of poly-ferric-aluminum-silicate-sulfate from oil shale ash. Chem. Eng. J., 2010, 163(1-2), 48-54.

8. Gao, G. M., Miao, L. N., Ji, G. J., Zou, H. F., Gan, S. C. Preparation and characterization of silica aerogels from oil shale ash. Mater. Lett., 2009, 63(30), 2721-2724.

9. Machado, N. R. C. F., Miotto, D. M. M. Synthesis of Na-A and -X zeolites from oil shale ash. Fuel, 2005, 84(18), 2289-2294.

10. Al-Qodah, Z., Shawaqfeh, A. T., Lafi, W. K. Adsorption of pesticides from aqueous solutions using oil shale ash. Desalination, 2007, 208(1-2), 294-305.

11. Abourriche, A., Benhammou, A., El hafiane, Y., Abouliatim, Y., Nibou, L., Oumam, M., Hannache, H., Birot, M., Smith, A. Effects of oil shale addition on the microstructure and mechanical properties of porous ceramics from Moroccan raw clay. IOSR Journal of Applied Chemistry (IOSR-JAC), 2015, 8(5), 13-21.

12. Abourriche, A. K., Oumam, M., Hannache, H., Birot, M., Abouliatim, Y., Benhammou, A., El Hafiane, Y., Abourriche, A. M., Pailler, R., Naslain, R. Comparative studies on the yield and quality of oils extracted from Moroccan oil shale. J. Supercrit. Fluid., 2013, 84, 98-104.

13. Moreno-Castilla, C., Carrasco-Marin, F., López-Ramón, M. V., AlvarezMerino, M. A. Chemical and physical activation of olive-mill waste water to produce activated carbons. Carbon, 2001, 39(9), 1415-1420.

14. Molina-Sabio, M., Rodriguez-Reinoso, F., Caturla, F., Sellés, M. J. Porosity in granular carbons activated with phosphoric acid. Carbon, 1995, 33(8), 1105-1113.

15. Benaddi, H., Bandosz, T. J., Jagiello, J., Schwarz, J. A., Rouzaud, J. N., Legras, D., Béguin, F. Surface functionality and porosity of activated carbons obtained from chemical activation of wood. Carbon, 2000, 38(5), 669-674.

16. Valix, M., Cheung, W. H., McKay, G. Preparation of activated carbon using low temperature carbonisation and physical activation of high ash raw bagasse for acid dye adsorption. Chemosphere, 2004, 56(5), 493-501.

17. Castro, J. B., Bonelli, P. R., Cerrella, E. G., Cukierman, A. L. Phosphoric acid activation of agricultural residues and bagasse from sugar cane: influence of the experimental conditions on adsorption characteristics of activated carbons. Ind. Eng. Chem. Res., 2000, 39(11), 4166-4172. 
18. Benadjemia, M., Millière, L., Reinert, L., Benderdouche, N., Duclaux, L. Preparation, characterization and methylene blue adsorption of phosphoric acid activated carbons from globe artichoke leaves. Fuel Process. Technol., 2011, 92(6), 1203-1212.

19. Bestani, B., Benderdouche, N., Benstaali, B., Belhakem, M., Addou, A. Methylene blue and iodine adsorption onto an activated desert plant. Bioresource Technol., 2008, 99(17), 8441-8444.

20. Legrouri, K., Khouya, E., Ezzine, M., Hannache, H., Denoyel, R., Pallier, R., Naslain, R. Production of activated carbon from a new precursor molasses by activation with sulphuric acid. J. Hazard. Mater., 2005, 118(1-3), 259-263.

21. Jaguaribe, E. F., Medeiros, L. L., Barreto, M. C. S., Araujo, L. P. The performance of activated carbons from sugarcane bagasse, babassu and coconut shells in removing residual chlorine. Braz. J. Chem. Eng., 2005, 22(1), 41-47.

22. Guan, B. T. H., Latif, P. A., Yap, T. Y. H. Physical preparation of activated carbon from sugarcane bagasse and corn husk and its physical and chemical characteristics. Int. J. Eng. Res. Sci. Technol. (IJERST), 2013, 2(3), 1-14.

23. Yang, K., Peng, J., Srinivasakannan, C., Zhang, L., Xia, H., Duan, X. Preparation of high surface area activated carbon from coconut shells using microwave heating. Bioresour. Technol., 2010, 101(15), 6163-6169.

24. Caturla, F., Molina-Sabio, M., Rodriguez-Reinoso, F. Preparation of activated carbon by chemical activation with $\mathrm{ZnCl}_{2}$. Carbon, 1991, 29(7), 999-1007.

25. Freeman, J. J., Gimblett, F. G. R., Roberts, R. A., Sing, K. S. W. Studies of activated charcoal cloth. III. Mesopore development induced by phosphate impregnants. Carbon, 1988, 26(1), 7-11.

26. Calahorro, C. V., Cano, T. C., Serrano, V. G. Effect of acid and heat treatments on surface area and porosity of a Spanish coal with high mineral matter content. Fuel, 1987, 66(4), 479-485.

27. Han, X., Wang, W., Ma, X. Adsorption characteristics of methylene blue onto low cost biomass material lotus leaf. Chem. Eng. J., 2011, 171(1), 1-8.

28. Avom, J., Mbadcam, J. K., Noubactem, C., Germain, P. Adsorption of methylene blue from an aqueous solution onto activated carbons from palm-tree cobs. Carbon, 1997, 35(3), 365-369.

29. Cavalier, J.-C., Chornet, E. Fractionation of peat-derived bitumen into oil and asphaltenes. Fuel, 1978, 57(5), 304-308.

30. Bekri, O., Ziyad, M. Synthesis of oil shale research and development activities in Morocco. In: Institute of Mining and Minerals Research (Ed.), Proceedings of the 1991 Eastern Oil Shale Symposium, Lexington, Kentucky, USA, 1991, 437-443.

31. Abourriche, A., Oumam, M., Larzek, M., Ichcho, S., Hannache, H., Pailler, R., Naslain, R., Birot, M., Pillot, J.-P. Elaboration and characterization of the pitches from Moroccan oil shale of Tarfaya. .Phys. Chem. News, 2003, 11, 10-15 (in French).

32. Yürüm, Y., Kramer, R., Levy, M. Interaction of kerogen and mineral matrix of an oil shale in an oxidative atmosphere. Thermochim. Acta, 1985, 94(2), 285-293.

33. Ichcho, S. Adsorbent materials from Moroccan oil shale of Timahdit and their applications in the removal of heavy metals and bacteria. $\mathrm{PhD}$ Thesis, Faculty 
of Sciences Ben M'sik, University of Hassan II, Casablanca, Morocco, 2003 (in French).

34. Christy, A. A., Dahl, B., Kvalheim, O. M. Structural features of resins, asphaltenes and kerogen studied by diffuse reflectance infrared spectroscopy. Fuel, 1989, 68(4), 430-435.

35. Aboulkas, A., Makayssi, T., Bilali, L., El harfi, K., Nadifiyine, M., Benchanaa, M. Co-pyrolysis of oil shale and high density polyethylene: Structural characterization of the oil. Fuel Process. Technol., 2012, 96, 203-208.

36. Langmuir, I. The adsorption of gases on plane surfaces of glass, mica and platinum. J. Am. Chem. Soc., 1918, 40(9), 1361-1403.

37. Freundlich, H. M. F. Über die Adsorption in Lösungen. Z. Phys. Chem., 1906, 57, 385-470 (in German).

38. Giles, C. H., Nakhwa, S. N. Studies in adsorption. XVI. The measurement of specific surface areas of finely divided solids by solution adsorption. J. Appl. Chem., 1962, 12(6), 266-273.

39. Ichcho, S., Khouya, E., Fakhi, S., Ezzine, M., Hannache, H., Pallier, R., Naslain, R. Influence of the experimental conditions on porosity and structure of adsorbents elaborated from Moroccan oil shale of Timahdit by chemical activation. J. Hazard. Mater., 2005, 118(1-3), 45-51.

40. Castro, J. B., Bonelli, P. R., Cerrella, E. G., Cukierman, A. L. Phosphoric acid activation of agricultural residues and bagasse from sugar cane: Influence of the experimental conditions on adsorption characteristics of activated carbons. Ind. Eng. Chem. Res., 2000, 39(11), 4166-4172.

41. Legrouri, K., Ezzine, M., Hannache, H., Donoyel, R., Pallier, R., Naslain, R. Removal of organic and inorganic pollutants by activated carbon elaborated from molasses. Ann. Chim. Sci. Mat., 2001, 8383-8389 (in French).

42. Bacaoui, A., Yaacoubi, A., Bennouna, C., Dahbi, A., Ayele, J., Mazet, M. Characterisation and utilisation of a new activated carbon obtained from Moroccan olive wastes. J. Water Supply Res. T., 1998, 47(2), 68-75.

43. Elharti, M., Legrouri, K., Khouya, E., Hannache, H., Fakhi, S., El Boucchti, M., Hanafi, N., Solhy, A., Hammouti, B. Preparation of adsorbent material from Moroccan oil shale of Timahdit: Optimization of parameters processes and adsorption tests. Der Pharma Chem., 2012, 4(5), 2130-2139.

Presented by $O$. Träss

Received July 22, 2019 